\title{
ENGLISH TEACHERS' CHALLENGES IN TEACHING ENGLISH: A CASE STUDY AT SMA KARYA IBU PALEMBANG
}

\author{
Meggi Lestari \\ Faculty of Teacher Training and Education PGRI University of Palembang \\ Meggilestari@gmail.com
}

\begin{abstract}
The English teachers at SMA Karya Ibu Palembang face numerous difficulties. The difficulties stemmed from the students and the school's facilities. The purpose of this study was to ascertain how teachers cope with difficulties in teaching English and to ascertain their strategies for overcoming those difficulties. The teachers of English at SMA Karya Ibu Palembang participated in this study. This study incorporated qualitative research. The data were gathered via interview. Meanwhile, to ascertain the difficulties encountered by teachers while teaching, the data gathered from the interview were analysed using thematic analysis. The findings established It was discovered that five factors contributed to teachers' difficulty in teaching English. This study demonstrates that teachers faced obstacles such as limited mastery of instructional methods, overcrowded classrooms, and insufficient facilities and resources. On the other hand, students face additional difficulties due to a lack of vocabulary mastery, low concentration, lack of motivation, pronunciation issues, and speaking issues. To address these issues, teachers employ a variety of strategies when teaching English. To begin, utilising a variety of teaching methods and techniques. Second, the teacher made the best possible use of the available resources and facilities. The third is providing constructive feedback.
\end{abstract}

Keywords: Challenges, Strategy, Teacher, Teaching.

\section{INTRODUCTION}

Teaching is the process by which teachers transfer knowledge and serve as role models for their students. Brown $(2000$, p. 7$)$ defines teaching as "demonstrating or assisting someone in learning how to do something, giving instructions, guiding in the study of something, providing knowledge, or causing someone to know or understand." However, teaching a language has a variety of distinct characteristics. According to Songbatumis (2017, p. 55), a teacher not only teaches and monitors students' language abilities, such as reading, writing, listening, and speaking, but also assists, facilitates, and encourages students' enthusiasm, positive attitude, and motivation for English. Thus, 
language instruction requires a teacher to instruct students, and teachers must be capable of developing all roles associated with the teaching and learning processes in the classroom.

Indeed, students encounter numerous difficulties while learning English, which can pose difficulties for English teachers. Lynch (2008) identifies three critical issues confronting English language teachers and students in the classroom: 1) a lack of motivation on the part of students, 2) insufficient time, resources, and materials, and 3) overcrowded English classes. (Abrar, 2016, p. 95). While Alrawashdeh \& Zayed (2017, p. 167) argued that teachers face a variety of challenges that contribute to the process being slow and somewhat ineffective. This issue puts teachers in a bind when confronted with the difficulties inherent in educating students for the future. In short, teaching English presents a variety of difficulties, the sources of which can be students or teachers.

In general, Kajhloo (2013) identifies several difficulties in teaching English as follows: a lack of interest and motivation for learning English, a lack of concentration in the classroom, prominent students of others, a lack of proficiency in teaching English by the majority of English teachers, and a lack of repetition and frequent practise by students. Additionally, there are three additional difficulties not mentioned previously. Lynch (2008) identifies three major impediments to English teaching and learning as follows: a lack of student motivation, insufficient time, resources, and materials, and an overcrowded classroom (as cited in Fajaryani, Masbirorotni, Nuraini, Nafrial \& Nopianti, 2018, p. 67). This demonstrates the importance of taking the challenge of teaching English more seriously.

According to my preliminary study at SMA Karya Ibu Palembang, an interview with two teachers revealed some difficulties in teaching English at the school. To begin, students face numerous writing difficulties. This occurred as a result of the students' lack of vocabulary and grammar, particularly in terms of selecting appropriate words and combining them into a coherent paragraph. Second, students frequently encounter difficulties speaking English. They are unable to express their emotions and ideas in English due to a lack of appropriate words. Additionally, they are unable to pronounce the words correctly and have no idea what to say. Thirdly, the students are unmotivated. This occurred as a result of the parents' lack of motivation. They do not allow their children to master English by offering private lessons or enrolling them in English classes. 
Parents expect the school to serve as a repository for their children's knowledge. Finally, the school's facilities did not support the teaching and learning of English. The equipment available, such as the LCD projector and sound system, was extremely limited.

Several previous studies have been conducted in this case to ascertain the difficulties associated with teaching English. Songbatumis (2017) conducted the first study at MTSN Taliwang, Indonesia, and discovered that teachers faced a lack of training, limited mastery of teaching methods, ignorance of information and technology, a lack of professional development opportunities, insufficient facilities and resources, and time constraints. Milon (2016) conducted a second study in rural primary schools in Bangladesh and discovered that teachers lacked adequate pedagogical knowledge, class sizes were too large, contact hours were too few, teachers lacked proper quality, teachers lacked proper training, and students lacked language skills. Then, in Birmingham, England, Copland, Garton, and Burns (2014) demonstrated that teachers faced challenges due to a lack of training, knowledge, and resources.

Considering the foregoing, this study will be conducted to ascertain the difficulties encountered by English teachers. "English Teachers' Struggles at SMA Karya Ibu Palembang" The study's problem was "what are the difficulties encountered by English teachers in teaching English at SMA Karya Ibu Palembang?" The purpose of this study was to ascertain the difficulties encountered by English teachers while instructing students at SMA Karya Ibu Palembang.

\section{LITERATURE REVIEW}

\section{The concept of Teaching}

Teaching is process transferring knowledge, studying something, and doing something until someone knows or understands what they learned. Harmer (2007, p. 105) argues teaching as about the transmission of knowledge from teacher to students, or about creating conditions in which, however, students learn for their own. Teaching is important because its function is to provide guidance and help the students improve their thinking in learning as defined by Brown (2000, p. 7) defined, teaching is guiding and facilitating learning, enabling the students, regulating the conditions for students. According to Arends (2009, p. 4), teaching offers a bright and rewarding career for those who can meet the intellectual and social challenges of the job. Teaching is also an art that is based on 
teacher experience and the practice of wisdom. It means that a teacher has responsibility to guide the learners in learning process and also to fulfill the goal of studying itself.

In addition, teaching English becomes a crucial issue when taught as a foreign language. Brown (2007) states that teaching cannot be defined apart from learning. Teaching is guiding and facilitating learning, enabling the learner to learn, setting the conditions for learning (as cited in Jaya and Marleni, 2018, p. 160). According to Patil (2008), teaching English dies not only delever knowledge to the students; on the contrary, it enables them to read, speak, and write fluently (as cited in Rasheed, Zeeshan \& Zaidi, 2017, p. 149). Teaching has the important role in teaching-learning English.

Teaching English is an enjoyable experience, and helping our students is rewarding. Baker and Westrup (2000) claim that teaching English is an important job and many governments and ministries of education believe that it is important for students to learn English. In many countries, secondary school and university courses are taught in English. However, the English language classroom also presents challenges that can test our patience and ability to be effective. In teaching English, there are four language skills learned by students such as listening, speaking, writing, and reading.

In addition, teachers are very instrumental in improving the quality of the students. Snow (2002) argues that teacher quality is one of the most critical variables in students' achievement. Furthermore, Snoek (2009) claims that teachers are considered the most important in-school impact factor on the quality of student achievement. From this statement, it can be concluded that a good teacher will teach excellent teaching and will make the students become good learners.

\section{The Roles of the Teachers}

Teachers play a necessary role in fostering the children's intellectual and social development of children during their formative years. The education that students get is the key to deciding that students' future. Teacher acta as facilitators or individual instruction guide to help students learn and apply concepts in subject. According to Harmer (2007, p. 57), there are five roles of the teacher including controller, prompter, participant, resource and tutor. 


\section{Controller}

The teacher takes full responsibility for the class, what students did, what they say and how they say it. Teacher takes on this role when new language are introduced and accurate reproduction and drilling techniques are required.

\section{Prompter}

The teacher encourages students to participate and provides suggestions on how students can continue in an activity. Teacher should help student students only when necessary.

\section{Participant}

This role improves the atmosphere in the classroom when the teacher participates in an activity. Also, the teacher puts a risk of dominating the activity while carrying it out.

\section{Resources}

The teacher is a kind of mobile resource center (monitor) that is ready to offer assistance if required or provide any language that is lacking for students when carrying out communicative activities. Teacher should make themselves available so that students can consult with them when (and only when) they hope.

5. Tutors

The teacher takes part as a coach when students are involved in project work or independent study. Teachers provide suggestion and guidance and help students clarify ideas and limit assignments.

Meanwhile, Jagtop (2016, p. 3902) also describe the role of teacher, as follow:

\section{Guide}

Teacher is guide philosopher and friend of student's teacher should guide to student enthustically. Mostly time students live in school and front of teacher. Therefore teacher find out which is qualities in our students. And teacher should give opportunity to student's qualities. Teacher can involve to student in various programs in the school.

\section{Counselor}

Teacher understand the students' problems. Study habits problems, lack of poor achievement, frustration, economical problem, family problem teacher help to students in these problems as a counselor. 


\section{Information provider}

Teacher should update in our subject and education system, around the country, and around the world. Teacher should understand new trends and research field of education. Teacher enhances general knowledge of our students.

\section{Facilitator}

Teacher can do important role in school as facilitator. Teacher facilitate to students our subject material, teacher facilitate to students magazines, newspaper, motivational story book.

In addition, Harden and Crosby (200) state that there are six areas of activity of the teacher. It can be summarized as: (1) the teacher as information provider, (2) the teacher as role model, (3) the teacher as facilitator, (4) the teacher as assessor, (5) the teacher as planner, and (6) the teacher as resource developer.

\section{The Concepts of Learning}

Learning is the process of acquiring new understanding, knowledge, behaviors, skills, values, and preferences. According to Brown (2007), learning is acquiring or getting of knowledge of subject or a skill by study, experience, or institution. However, Houwer, Holmes, and Moors (2013) explain that learning has been defined functionally as changes in behavior resulting from experience or mechanistically as changes in the organism result from experience. So, it can be defined that learning is a process of getting information, improving knowledge and experiencing something personally. People can get knowledge from what they learned and experienced.

Graves (2008) mentions that the purpose of learning English is to be global citizen in order to communicate and to improve one's economic prospects. English is used in many concerns for education, job, information, and entertainment (as cited in Jaya, Hermansyah, and Rosmiyati, 2019, p. 4). According to Nga (2008) English is the main language of books, newspapers, airports and air-traffic control, international business and academic conferences, science, technology, medicine, diplomacy, sports, international competitions, pop music, and advertising. Over two-thirds of the world's scientists write in English. Three-quarters of the world's mail is written in English (Nga, 2018). Of all the information in the world's electronic retrieval systems, $80 \%$ is stored in English. 


\section{Factors Causing Learning Difficulties}

Learning difficulties become a major obstacle in teaching and learning. The difficulties in learning can be caused by student factor, teacher factor and school factor.

\section{Student Factor}

Problems that encountered by pupils can be causing problem for a teacher within teaching process. Nadirah (2014) explained that learning difficulties of student can be evident from the emergence;

1) Declining academic performance or a learning achievement.

2) Behavioral abnormalities (misbehavior), such as noise in the classroom, harassing friends, fighting, often not attending school, often running away from school.

3) Broadly speaking, these factors that cause learning difficulties consist of two kinds, namely:

a. Internal factors of students, example things or circumstances that arise from within the students themselves.

b. External factors students, namely things or circumstances that come from outside the student self.

These two factors include the various things and circumstances which, among others, are below:

1) Internal Student Factor

Internal factors of students include disorders or lack of psycho-physical ability of students, namely:

a. Cognitive (creative), such as low intellectual capacity / student intelligence;

b. Affective (flavor), such as emotional instability and attitude;

c. The psychomotor, among others, such as disturbances sensory devices and listeners (eyes and ears).

2) External Factors Students

Student external factors include all circumstances and conditions surrounding environment that does not support student learning activities.

These environmental factors include: 
a. Family environment, for example: disharmony relationship between father and mother, with low family economic life.

b. Village / community environments, for example: slum areas, and mischievous peer groups.

c. The school environment, for example: the condition and location of school buildings such as near poor markets, the condition of teachers and learning tools of low quality.

\section{Teacher Factor}

Besides student is factor, teacher is factor which has become a main problem in learning. Dalyono (2010) mentioned some factors that the students themselves do not only cause learning difficulties. The teacher factor is related to teachers' qualifications, teacher's relationship, teacher ability, and teaching method. The teacher can also be the cause of learning difficulties due to several things as follows;

1) Teachers are not qualified, either in the method that is used or the subject itself. This may happen because the teachers' subject is less suitable, to less control even more if less preparation so the way to explain is less clear, difficult to understand by students.

2) The teacher's relationship with a student is not good. This starts with the nature and attitudes of the teacher whom the students do not like, such as;

a. Rude, angry, mocking, never smile, do not like to help children, snap, and others.

b. Not clever to explain, cynical, arrogant.

c. Irritating, high-minded, stingy in scoring, unfair, and so on.

3) Teacher attitudes like this do not favor students, to inhabit development of children and result in the relationship of the teachers with students is not good.

4) Teachers demand standard of learning above the students' abilities. This is common in young teachers who are inexperienced until they can measure students' ability, so that only a small percentage of students can succeed well.

5) Teachers lack skill in the effort to diagnose learning difficulties. For example in talents, interest, traits, student needs, and so on.

6) Teaching methods used by teachers can lead to learning difficulties, as follows;

a. Teaching methods that cause students to become passive so that makes students less active. 
b. Teachers use unattractive teaching methods that cause students less interest in following the lesson.

c. Teachers only use one method only and there is no variation of teaching methods.

\section{School Factor}

Facilities and infrastructure provided by schools can help teachers and students in the learning process. However, the lack of facilities and infrastructure can be a challenge for teachers in teaching. Besides that, there is another problem such as; incondusive classroom and classroom condition.

Poor room conditions will hamper learning process. If some requirements cannot be fulfilled that will make learning and teaching cannot run effectively. According to Dalyono (2010), the room must fulfill the health requirements such as;

1) The room should have a windows, enough ventilation, fresh air in the room, the light can illuminate the room.

2) The walls should be clean and do not look dirty.

3) The floor is not muddy, slippery and dirty.

4) The state of the building is far from crowded places (markets, workshops, factories, etc.) so that student can easily concentrate in learning.

Based on Vygotsky's theory of social development, students' learning development can be determined by the classroom environment because students spend their time learning mostly in the classroom, although learning can occur in other venues (as cited in Wei \& Elias, 2011 p. 240). Moreover, Yan (2006) said that classroom is the main place for foreign language learners where they are frequently exposed to the target language. Therefore, creating a conducive learning environment by providing a sufficient classroom environment physically and social psychologically are important. p. 77). In brief, a conducive classroom environment is needed in the teaching and learning process, which is very influential on students' learning development.

\section{Diagnosis of Learning Difficulties}

In making the diagnosis required the existence of a procedure consisting of certain steps oriented to the discovery of certain types of learning difficulties experienced by 
students. Such a procedure is known as "diagnostic" learning difficulties. Many diagnostic steps that can be taken by the teacher, among others are quite well known is the procedure of Weener \& Senf (as cited in Syah, 2003, p. 174) as follows:

1) Conduct class observations to see students' deviant behavior when attending lessons;

2) Checking the sightings and hearing of students in particular who are suspected of having learning difficulties;

3) Interviewing parents or guardians to learn about family issues that may cause learning difficulties;

4) Provide diagnostic tests of certain skills field to know the nature of learning difficulties experienced by students;

5) Provide intelligence ability test (IQ) especially to students who have learning difficulties.

\section{Some Challenges in Teaching English}

There are several issues in education emerging from the school itself and the quality of the teacher that influences student performance. Lynch (2008) stated that many experts call for school vouchers, smaller classes, more standardized testing, or rigorous teacher accrediting as the key to improving student performance in today's educational debates. Remarkably, none of these approaches addresses what actually goes on in the classroom (as cited in Fajaryani, Masbirorotni, Nuraini, Nafrial, \& Nopianti, 2018, p. 66). If the issues are not resolved, these issues will become serious problem.

Teaching English is not always running well. The teachers of English have some major challenges in teaching English in classroom. According to Lynch (2008), there are three most crucial challenges in teaching and learning English in the classroom: First, lack of motivation, learners may not have inspired and interested in learning English. They have even fear of failure in exams and even in classroom interaction and so they cannot get involved easily in classroom interaction and learn the language comfortably. They must be motivated by teachers and scope to learn English in classroom interaction. Second, insufficient time allocation, resources, and materials, English is a foreign language and hence it cannot be learnt and taught as easily as mother tongue or first language. And when it is learnt or taught as second language, it requires long time and 
simultaneously adequate resources and materials to create English classroom climate which facilitate teaching-learning process.

Third, over-crowded classes, the number of students in a classroom can range from one, for those who teach individual private students, to fifteen or twenty students in a typical classroom up to multitudes of thirty-five or forty or even fifty or more students packed into a language leaning situation. The large classes create several problems such discomfort in the class, less attention, evaluation, difficulty in managing class, maintaining learning effectiveness, etc. (as cited in Fajaryani, Masbirorotni, Nuraini, Nafrial, \& Nopianti, 2018, p. 66). Those three main challenges, as mentioned above, are necessarily needed to be overcome to improve quality of English Language Teaching.

Teaching English has three main challenges for the teachers that teach English as a foreign language. Copland, Garton and Burns (2014, p. 739-741) mention that there are three challenges commonly faced by English teachers in teaching English, as follows:

1. Teachers' Proficiency

A good proficiency level is needed for a teacher, especially for English teachers. Unfortunately, many teachers have low proficiency level. Teachers' low proficiency levels, or their lack of confidence in their ability, is consistently identified in the literature.

2. Classroom Management

Many English teachers have difficulty in teaching English especially in large classes which a classroom consists of more than 30 students.

\section{Government Policy and Curricula}

One challenges for teachers is that a teacher must teach based on the curriculum and policies set by the government.

In addition, Khan (2011, p. 70-77) explains that there are several challenges in teaching of English and learning English as foreign language in Islamic environment, as follows:

\section{Background of English teachers}

The teacher is the most important element in any educational programmed. The teacher has big responsibility to deliver the subject to the students. To better 
understand what language teacher education should be, it is important to take a closer look at the knowledge base of foreign language teachers of English, their pre-service education, and in-service training.

2. Poor ability

Arab students' challenges in learning English usually spring from the following reasons; a) school graduates have lack of information regarding the university or collage they enrolled in, b) there is deficiency in the English language curricula offered by some schools and universities, c) poor teaching methodology; and d) problems with proper language environments. These conditions make the students getting rare to participate in learning English.

3. Lack of management

The management can be defined as the minimum because they have limited resources. The teacher will be easy to deliver the subject matter to the students if the institution can provide a good management to the teachers.

\section{Challenges in Teaching Reading}

Most of the students in Indonesia often get difficulties to understand the printed message. They do not know how to read meaningfully. They only read the text book required to be able to perform well in the achievement test. In spite of this, most of them get low mark in reading comprehension exercises, because they have no any techniques in read meaningfully. Furthermore, Snow (2002, p. 11) states that reading comprehension as the process of simultaneously extracting and constructing to emphasize both the importance and the insufficiency of the text as a determinant of reading comprehension.

The teachers face some problem in teaching language skill. There are several challenges in teaching reading comprehension that proposed by Westwood (2008) as follows:

1. Limited vocabulary knowledge

2. Lack of fluency

3. Lack of familiarity with the subject matter

4. Difficulty level of the text

5. Inadequate use of effective reading strategies

6. Weak verbal reasoning 
7. Problems with processing information

8. Problems in recalling information after reading

\section{Challenges in Teaching Writing}

There are several challenges in teaching writing. Westwood (2008) state that there are some challenges in teaching writing cause some factors. The factor are: 1) Lack of proficient spell, 2) Students are usually reluctant to review, edit and polish a first draft, 3) Weaker student tend to be preoccupied with the mechanical aspects of writing.

\section{Challenges in Teaching Speaking}

Besides reading and writing, teacher also face some challenges in teaching speaking. Harmer (2007) has reported that students are often reluctant to speak because they are shy and are not predisposed to expressing themselves in front of other people, especially when they are being asked to give personal information or opinions. Students often feel worried about speaking badly and thus losing face in front of their classmates. In fact, selecting the most appropriate types of spoken discourse for classroom practice in a particular language course is also a very hard.

\section{Challenges in Teaching Listening}

The last, the teachers face some challenges in teaching listening. Teaching listening is thus the starting point in teaching English as a foreign language. It is one the basics for establishing good knowledge for communication. It is also the first skill that deals with child learning acquisition, so the child can begin their external relations through listening. Ahmed (2017) found that the teacher faces some challenges in teaching listening. The challenges are:

1. The number of listening laboratories is not adequate

2. Listening material on tape lacks visual and aural environmental clues.

3. The selection of listening books in level two and level four is not appropriate for the students' standard.

4. The listening laboratories are not well-organized and provided with all kinds of digital facilities.

5. The large class is a big problem for teaching listening skill. 
6. There is no auditory and visual library for students to practice listening skill.

7. The deficient linguistic knowledge of the students.

\section{Students and Teachers in this Era}

In this industrial revolution 4.0 era, due to the demand of education in this era is not merely focus on the intellectual development but also creativity. According to Nizam (2006), the assessment in Indonesia directed at HIGHER Order Thinking Skills (HOTS). The policy refers to the need for life skills in the $21^{\text {st }}$ century (as cited in Widana, p. 32). However, the partnership for $21^{\text {st }}$ century skills (2011) formulated framework for $21^{\text {st }}$ century skills; 1) learning and innovation skills, 2) life and career skills, and 3) information, media, and technology skills (Scott, 2017). Furthermore, Scott (2017) and Bialik (2015) state that the $21^{\text {st }}$ century skills can be grouped into two main components; abstract skills related to thinking skills (creative thinking and critical thinking), and concrete skills (communication and collaboration) (as cited in Retnawati, Djidu, Kartianom, Apino, Risqa \& Anazifa, 2018, p.216). Creative thinking skills and critical thinking skills are parts of higher order thinking skills (HOTS) (Miri, David, \& Uri, 2007, p.2). Therefore, higher order thinking skills (HOTS) are essential components for industrial revolution 4.0.

\section{The Impact of Challenges in Teaching English}

In teaching English has many impacts of challenges. According to Lynch (2008), students may not be inspired and interested in learning English. They are even afraid of failing the exam and even in classroom interactions so they cannot engage easily in classroom interaction and learn the language comfortably. They need sufficient motivation from the teacher and the scope to learn English in classroom interactions. Second, insufficient time, resources, and materials, English is a foreign language and cannot be learned and even taught as easily as mother tongue or first language. When studied or taught as a foreign language, it is complicated and takes a long time to learn and the resources and materials simultaneously to create an atmosphere of English class facilities are inadequate for teaching and learning.

Then, the overcrowded English class, the number of learners in the classroom can range from one, to those who teach private students, to fifteen or twenty students in 
ordinary classrooms to "a great deal of thirty-five or forty or even fifty or more learners who are put into a lean language situation. The over-crowded class creates a number of issues such as classroom discomfort, individual attention, evaluation, classroom management, maintaining the effectiveness of learning, etc. These three important challenges, as mentioned above, need to be addressed to improve the quality of English language teaching.

\section{The Implementation of Curriculum 2013 in the Learning Process in SMA Karya Ibu Palembang}

In EFL classroom at Senior High School, either teachers, students, teaching methods and teaching materials are expected to facilitate the aim of EFL teaching which is intercultural communicative competence. Based on the documents emerged by the Minister of National Education, the goals of English teaching at Senior High School level are:

- to improve communicative competence both in oral and written to gain functional literacy level,

- to raise the awareness about the importance of English to raise the competitiveness of the nation, and

- to develop students' understanding about the connection between language and culture.

Learning English, which is most commonly done in schools today, has the following characteristics: teaching material is based on textbooks, learning actions are mostly written, the learning step begins with the teacher's explanation of one or two examples of text about the content and elements of language. Then, students work on written questions in the textbook, and finally produce the text independently according to the examples in the textbook and teacher's explanation (Ministry Education \& Culture, 2013). Thus, the process of learning English must be done by learning the material in accordance with the textbook and doing the task both oral and written.

In the learning process, the teachers need to guide the students. Guiding students to find out, not being told and emphasizing language skills as a communication tool, knowledge bearer, logical, systematic, and creative thinking (Ministry Education \& Culture, 2014). Language skills is needed but the teachers also have a role in guiding the 
students. Moreover, in learning English using the 2013 curriculum, there are some changes in the learning process, especially in English, as follows; a). The material presented is emphasized in language competence as a communication tool to convey ideas and knowledge.

\section{METHOD AND PROCEDURE}

\section{Research Design}

In this study, the writer used qualitative research with a descriptive design. Qualitative research focuses on studying social phenomena and giving voice to the feelings and perceptions of the participants under study. Qualitative research is a study that investigates the quality of relationships, activities, situations, or materials (Fraenkel, Wallen and Hyun, 2012, p. 426). However, According to Knufer and McLellan (n.d. p. 1196), descriptive research refers to the types of a research question, design, and data analysis that will be applied to a given topic and tells what is, while inferential statistics try to determine cause and effect. I used descriptive research to analyze English teachers' personal experiences, elaborate on the challenges faced by teachers of English in-depth at SMA Karya Ibu Palembang.

\section{Research Site and Participants}

In this study, the writer chose teachers of English who teach at SMA Karya Ibu Palembang as the participants, which consist of two English teachers. In this study, I used homogeneous sampling technique to choose the participants. According to Creswell (2012), homogeneous sampling technique is a technique sampling based on individuals or groups that have particular characteristics such as, they are teaching in the same school, they have teaching experience of more than five years and they have been certified. I chose the participants based on several characteristics, such as; had a good credibility, knowledgeable, experience in teaching English, and still active in teaching English. The participants of this research are the teachers of English at SMA Karya Ibu Palembang which consist of two teachers of English who will be interviewee in this study. This research was conducted at SMA Karya Ibu Palembang which was located in Jl. Sosial no. 510, Ario Kemunjng Palembang. The research was focused on challenges to teach 
English and the strategies in dealing with the challenges. This research was done during $6^{\text {th }}$ July $-7^{\text {th }}$ July 2020 . The interview was done at the teacher's room.

\section{Data Collection}

I used a semi-structure interview to collect the data. Interviews were considered more powerful in eliciting narrative data that allows the researcher to investigate people views in depth. The interview was used as another instrument to find the challenges faced by English teachers in teaching English at SMA Karya Ibu Palembang. It took about 1, 5 hours. In addition, according to Cresswell (2012, p. 387), there were four types interview: one-on-one interview, focus group interview, telephone interview, and electronic Email interview. In this research, the writer used one-on-one interview. Creswell (2012, p. 340) argues that one-on-one interview is how the interview gets the data by asking one interview at a time. Thus, a one-on-one interview was one person interviewing another person to get more result from the interviewee.

Open-ended questions were used to elicit information from teachers about the factor of their challenges in teaching English. Then, open-ended responses to a question allowed the participant to create the options for responding (Creswell, 2012, p. 220). In the interview process, there were some steps; first, the writer prepared the instrument of the interview. In this research, an interview protocol was an instrument in interviewing the English teacher. Second, the writer recorded the interview section as the data and there were 15 questions and the interview was end after the interviewee finished answering the questions. Last, interview was conducted until the data collected.

\section{Data Analysis}

In analyzing the qualitative data, the writer used interview data to know the teachers' challenges in teaching English at SMA Karya Ibu Palembang. In analyzing the qualitative data, the writer used semi-structure interview. In interview process, there were some steps. The first step, the writer ensured the data collected from interviews with English teachers at SMA Karya Ibu Palembang. The second step was generating initial codes in this step, the writer coded the data from interview. The third was searching for themes; the writer made themes based on code. The fourth was reviewing themes; the writer reviewed the themes that the writer made. The fifth was defining and naming 
themes; the writer redefined and renamed the themes to be more complex. The last was producing the report, this the writer made the explanation of the result about challenges in teaching English at SMA Karya Ibu Palembang.

In this study, trustworthiness was used to validate the data by applying member checking. Creswell (2014) mentions eight strategies in validating the data: triagulate, use member checking, thick descriptions, clarify the bias, present descrepant information, long periods of time, peer debriefing, and using external auditors.

One of the strategies that used was member checking. According to Creswell (2005), member checking is a process in which researchers ask one or more participants in study to check the accuracy of the account. This examination involves bringing the findings back to the participants and asking them (in writing or in interviews) about the report's accuracy. In member checking, I delivered the transcript and data interpretation to the participants to verify the data accuracy.

\section{FINDING}

The study's findings begin with the difficulties encountered by the teacher while teaching English to the participants. Participants included two English teachers: participant 1 (Ridho, S. Pd) and participant 2. (Haryono, S. Pd). Interviews were used to elicit information about the difficulties teachers face when teaching English. The English teacher at SMA Karya Ibu Palembang faces numerous obstacles. The difficulties encountered are diverse in nature and are related to students, teachers, and facilities. The following are the specific reasons for their difficulties:

\section{Based on your teaching experience so far, what are your difficulties in teaching}

\section{English?}

The first teacher said that "I am difficult to invite the students to speak, because they have lack of vocabulary. I implemented monthly diary writing and applied various games to improve their students' vocabulary mastery. Also I asked the students to bring dictionary when they have English class".

However, the second teacher said that "the main challenge in achieving teaching and learning goal was students' lack of vocabulary mastery. Making the students to speak is quite difficult. I provided the list of vocabulary behind the copies of the materials. 
However, I selected simple words and diction to be used in teaching English when I explained the material.

According to the statements above, the first teacher found it difficult to invite students to speak due to their limited vocabulary. He implemented monthly diary writing and used a variety of games to help students improve their vocabulary mastery in order to solve problems. Additionally, he requested that students bring a dictionary to English class.

However, the second teacher stated that the primary obstacle to achieving teaching and learning objectives was students' lack of vocabulary mastery. It's quite difficult to get students to speak. To resolve the issues, he concealed the vocabulary list behind the copies of the materials. However, he chose simple words and diction to explain the material in English.

\section{What makes you frustated in teaching English?}

The first teacher said that "There is no improvement in students' speaking skill because they are mostly afraid of making mistakes". Also, the second teacher said that “students' speaking skills are not improved since most students are timid".

Based on the statements above, the first teacher said that there was no improvement in students' speaking skill because they are mostly afraid of making mistakes. While, the second teacher said that students' speaking skill is not improved since most of students are timid.

\section{What makes teaching English difficult for you?}

The first teacher said that "The available facilities in the school did not support English teaching and learning process. The devices such as LCD projector and sound system were very limited in which there was only one device that could be used by all teachers. Since there was very limited device of sound system, I taught listening only through my own voice”. Meanwhile, the second teacher said that "the availability of K13based books were barely provided, especially books for the eleventh grade students. I still used KTSP (School-Based Curriculum) books if the topic discussed was similar”.

According to the statements above, the first teacher stated that the school's facilities did not support the teaching and learning of English. The devices, such as the 
LCD projector and sound system, were extremely limited, with each teacher having access to only one device. To resolve the issues, and due to the limited capabilities of the sound system, he taught listening exclusively through one's own voice.

However, the second teacher stated that K13-based books were scarcely available, particularly for eleventh-grade students. He continued to use KTSP (School-Based Curriculum) books to resolve the issue if the subject was similar.

\section{What bad experiences do you have in teaching English?}

The first teacher said that "I faced in teaching songs to students. In K13 (Curriculum of 2013) there is a topic about songs in which I sometimes does not teach it because I cannot sing. In teaching listening, I searched for songs on the internet although I did not know how to sing them. Then, I let students listen to the songs I had downloaded". However, the second teacher said that "I sometimes feel unconfident in what and how I teach".

According to the statements above, the first teacher stated that in K13 (the 2013 curriculum), there is a topic about songs that he occasionally skipped due to his inability to sing. He searched the internet for songs to teach listening, despite the fact that he did not know how to sing them. The first teacher then allowed students to listen to the downloaded songs. However, the second teacher occasionally expresses reservations about what and how I teach.

What problems bother you related to your English teaching that you cannot stop thinking about way have to solve it?

The first teacher said that "some students might have lack of vocabulary mastery which makes them not actively participate in class". Furthermore, the second teacher said that "the students is difficult to pronounce and differentiate the spelling. For example, they pronounce "name" (neim) as name. I used dialogues in order to teach pronunciation.

According to the statements above, the first teacher stated that some students may lack vocabulary mastery, resulting in their inability to participate actively in class. Additionally, the second teacher stated that the students have a difficult time pronouncing 
and distinguishing their spelling. To address the issue, he used dialogues to instruct students on proper pronunciation.

\section{What problems do you have in mastering the material?}

The first teacher said that "I do not think I could teach my students maximally due to difficult materials to be taught. I selected simple words and diction to be used in teaching English when I explained the material." Also, the second teacher said that "because of difficult lesson, many of my students were confused when I taught them the materials".

According to the statements above, the first teacher was unable to teach the students to their full potential due to the difficult materials being taught. As a result, he chose simple words and diction to use when explaining the material in English. While the second teacher emphasised that many of the students were perplexed as he explained the materials to them.

\section{How do you describe the class size of your classes?}

The first teacher said that "in my English class, there are approximately 30-33 students in a classroom. English is not our language. If it is in large classes, it is ineffective". However, the second teacher said that "I did not enjoy teaching English because I have too many students in the classroom. It is around 32 students in each class".

As per that statements, both teachers indicated that their classes were overcrowded, with more than 30 students. This condition has an effect on teachers' attitudes and expectations. The first teacher shared that it would be ineffective in a large class. While the second teacher also disliked teaching English due to the overcrowding in the classroom.

\section{What problems do you face when teaching English with a large number of students?}

The first teacher said that "the class is noisy and loud. It made me difficult to control class and manage in learning process". Meanwhile, the second teacher said that "the students can play with their friends, disturb another students and the learning process is not efficient".

And according to statements above, the first teacher mentioned how noisy and loud the class is. It made it more difficult for the participant to maintain control of the 
class and manage the learning process. While the second teacher stated that students can interact with their friends, causing disruption to other students, and that the educational process is inefficient.

How do you describe your students' motivation in learning English and to what extent does their motivation become challenges for you in teaching English?

The first teacher said that "I caught a student who did not bring any books to school due to forgetfulness, while the other students intentionally left their books in the desk of the classroom. The first thing I do for students whose motivation is low is motivating them orally. For passive students, I often gave them motivational feedback". While, the second teacher said that "some of my students got bored in studying English when I taught a certain topic of the subject. It is because some of my students have already studied that in their primary schools and private courses. Regarding students' interest towards English, I gave them advices to keep studying”.

According with statements above, the first teacher shared that some students did not bring books to school due to forgetfulness, while others left their books on purpose in the classroom desk. He advised students with low motivation to be motivated orally. He frequently provided motivational feedback to passive students.

While the second teacher became dissatisfied with his students' progress in studying English when he introduced a new subject. This is because several students have already studied this material in their primary schools and private courses. In response to students' interest in English, he advised them to continue studying.

\section{Interpretation}

The study's interpretation was based on data analysis, which aimed to confirm and strengthen the findings. Based on the findings above, the researcher concludes that teaching English as a foreign language in a school setting is not easy; the teacher at SMA Karya Ibu Palembang faces numerous challenges.

The first is a lack of vocabulary mastery on the part of students. According to Hasan (2016), one of the most difficult tasks that students face is mastering vocabulary. The third issue is one of communication. The fourth issue is one of pronunciation. Khan (2011) stated that "specific pronunciation, stress, and intonation problems become a problem for students" (p. 72). 
The second is overcrowded classes. The large classes create several problems such discomfort in the class, less attention, evaluation, difficulty in managing class, maintaining learning effectiveness, etc. (as cited in Fajaryani, Masbirorotni, Nuraini, Nafrial, \& Nopianti, 2018, p. 66). The third is inadequate resources and facilities. Ajibola (2010) argued that ensuring the availability of sufficient textbooks, computers, listening devices, hands-on tools, and other teaching instruments is a challenging assignment.

The fourth is students' lack of motivation. According to Lynch (2008), there are three most crucial challenges in teaching and learning English in the classroom: first, lack of motivation, learners may not have inspired and interested in learning English. They have even fear of failure in exams and even in classroom interaction and so they cannot get involved easily in classroom interaction and learn the language comfortably. They must be motivated by teachers and scope to learn English in classroom interaction. Second, insufficient time allocation, resources, and materials, English is a foreign language and hence it cannot be learnt and taught as easily as a mother tongue or first language. And when it is learnt or taught as a second language, it requires a long time and simultaneously adequate resources and materials to create an English classroom climate which facilitates the teaching-learning process.

To address these issues, teachers employ a variety of strategies when instructing students in English. To begin, utilising a variety of teaching methods and techniques. In the classroom, teachers used a variety of teaching methods and techniques. The teachers used pictures and role-plays in teaching, implemented monthly diary writing and applied various games to improve their students' vocabulary mastery. Additionally, according to the Virginia Department of Education (2006), students can gain an understanding of English by managing their classrooms.

The teacher described that if she finds students do not concentrate, she would point them out and tell them to stop their activity. Brewster et al, (2002), when a teacher wants to gain students' attention, it can be done through "firmly name the children who still talking and say stop talking please and maintain eye contact" (p. 221).

Another thing the teacher would do for disciplined and misbehaved students was control and give them punishment, would not hesitate to involve smart students; those who have learned English outside the school to help her teach certain topics of the subject. Furthermore, in dealing with students' lack of vocabulary mastery, two participants ask 
students to bring a dictionary when they have English class or study club activity in the school. Fatiloro (2015) says that dictionaries, grammar guides, and the web should always be as the tool for consultation when teaching and learning English.

Second, the teacher used of available resources and facilities. The teachers agreed that they made use of available books to solve the shortage of K13 (Curriculum of 2013) books. They also argued that they still use KTSP (School-Based Curriculum) books if the topic discussed was similar. Furthermore, one of teacher preferred to use anything provided in the classroom i.e. chairs, whiteboard, window, and so on to be learning tools. On the other hand, since there was a very limited sound system device, he teaches listening only through her own voice. Mishra (2015) that "rural areas lack in the required ambience, teachers can make much use of the easily available resources" (p. 42).

Furthermore, Songbatumis (2017) found that the teacher were challenged by their lack of training, limited mastery of teaching methods, unfamiliarity to IT, lack of professional development, inadequate facilities and resources, and time constraint. On the other hand, the other challenges coming from students' side include lack of vocabulary mastery, low concentration, lack of discipline, boredom, and speaking problems. However, Milon (2016) found that most of the rural schools' students are weak in English due to lack of skilled and trained teachers, proper teacher training, proper teaching methods and materials, limited contact hours, class size, and inadequate knowledge pedagogy and so on.

Bayuaji (2008) found that the teachers were challenged by the problems which were divided into two categories, linguistic problem and non-linguistic problems. Different pronunciation between English with Indonesian became the problem of linguistics. While in non-linguistic problem, the main issues were class management, limited time of teaching, students' motivation to learn English, and the lack of ELT facilities.

Yulia (2013) found that students' low motivation challenged the teachers; in fact, the students' eagerness to listen to the teachers as the models of English language expressions was good. Teachers need to motivate students to learn English by improving their teaching techniques as well as their speaking competence in class to achieve student integrative motivation as English is valuable for them. 


\section{CONCLUSION AND SUGGESTION}

Based on the findings and discussion in the previous chapter, the researcher drew the conclusion:

The teachers at SMA Karya Ibu Palembang face difficulties in teaching English as a foreign language as a result of the students and the school's facilities. This study demonstrates that teachers faced difficulties due to limited teaching methods, overcrowded classrooms, and insufficient facilities and resources. On the other hand, students face additional difficulties due to a lack of vocabulary mastery, low concentration, lack of motivation, pronunciation issues, and speaking issues.

In order to overcome those problems, there are some strategies that the teachers use in teaching English. First, applying various teaching methods and techniques. Second, the teacher used of available resources and facilities. The third is giving motivational feedback

Based on the findings of this study, some recommendations are made for students, English teachers, and other future researchers. Students can learn English by memorising vocabulary or by enrolling in a course that requires them to use English in their everyday communication, particularly in their conversation class, and practise listening skills by listening to English music. For teachers, they must develop skills in teaching English, a willingness to create a variety of teaching materials, an understanding of the broad characteristics of the student language and the structure of English, and a warm, friendly attitude that will offset the students' lack of knowledge. Teachers should have a sound strategy in place to ensure that learning is enjoyable in the classroom. Discover and develop a novel approach to construction.

The third suggestion is provided especially for school to solve facilities problems. School should provide complete facilities to support learning English, such as providing a laboratory equipped with high-quality audio devices and computer, especially in teaching listening. Next suggestion, I also expect that the government needs to help schools by providing financial assistance and equipment or facilities to support teaching and learning processes at schools.

Finally, this study suggests that the next researcher conduct additional research on the difficulties associated with teaching English. The following researchers should provide additional explanation, identify new challenges that may affect English teaching, 
and propose solutions to mitigate or eliminate the problems. Thus, it is expected that this study will serve as a reference for the next researcher who conducts research on this title.

\section{ACKNOWLEDGMENTS}

Alhamdulillahirobbil'alamin. Praise is to Allah SWT, the Almighty for the mercy and strength so that I could finish this thesis. Invocation and peace go to Muhammad SAW, the Holy Prophet, his family and his disciples. May Allah bless and give them peace.

First of all, I would like to express the greatest gratitude to my beloved parents, sisters, brother, and friends for their love, and support which they give to me. Hopefully, Allah gives them the best of all. Furthermore, I would like to express my appreciation to the school for their assistance and cooperation. I also would like to express my great gratitude to my two advisors, Herlina, S.S., M.P.d and Hermansyah, M. Pd for their encouragement in writing this thesis. I also very grateful to the head of English Education Study Program and the Dean of Faculty of Teacher Training And Education Pgri University of Palembang for their assistance in administration matters. In addition, I would like to express my deepest appreciation to my parents, brothers, and my classmates for their love and support.

\section{REFERENCES}

Ahmed, F. E. Y. (2017). Challenges experienced by EFL university instructors in teaching listening skill: a case study of college of science and arts- Tanumah-King Khalid University. Imperial Journal of Interdisciplinary Research (UIR), 3(3), 11681182.

Jaya, A., Hermansyah, \& Rosmiyati, E. (2019). The implementation of project-based learning in increasing speaking achievement and self-confidence. Indonesian Educational Administration and Leadership Journal (IDEAL) 1(1), 4-14.

Jaya, A., \& Marleni. (2018). Teaching reading procedure text through conceptoriented reading instruction (cori) to the tenth grade students of state senior high school 13 Palembang. English Community Journal, 2(1), 158-166. 
Alhojailan, M. I. (2012). Thematic analysis: A critical review of its process and evaluation. West East Journal of Sciences, 1(1), 8-21.

Alrawashdeh, A. I., \& Al-Zayed, N.N. (2017). Difficulties that English teacher encounter while teaching listening comprehension and their attitudes towards them. English Language Teaching, 10(5), 167-178.

Arends, R.I. (2009). Learning to teach (9 ${ }^{\text {th }}$ ed.). New York, NY: McGraw-Hill.

Brown, H. D. (2000). Principles of language learning and teaching (4 ${ }^{\text {th }}$ ed.). New York, NY: Pearson Longman.

Cohen, L., Manion, L., \& Morrison, K. (2005). Research methods in education (5 ${ }^{\text {th }}$ ed.). London, England: Routledge Falmer.

Copland, F., Garton, S., \& Burns, A. (2014). Challenges in teaching English to young learners: Global perspectives and local realities. TESOL International Association, 48(4), 738-762. doi: 10.1002/tesq.148.

Creswell, J. W. (2012). Educational research: Planning, conducting and evaluating quantitative and qualitative research. Boston, CA: Pearson.

Derakhshan, A., \& Shirmohammadli, M. (2015). The difficulties of teaching English language: The relationship between research and teaching. International Journal of Linguistics, 7(1), 102-110.

Fajaryani, N., Masbirorotni., Nuraini., Nafrial., \& Nopianti. (2018). Different madrasah, but the same stories: Academic and non-academic challenges encountered by teachers in teaching a foreign language. Ta'dib: Journal of Islamic Education, 23(1), 65-86. Retrieved from http://jurnal.radenfatah. ac.id/index.php/ta'dib.

Fraenkel, J. R., Wallen, N. E., \& Hyun, H. H. (2012). How to design and evaluate reserarch in education ( $8^{\text {th }}$ ed.). New York, NY: The Mc-Graw Hill Companies.

Harmer, J. (2007). The practice of English language teaching ( $4^{\text {th }} \mathrm{ed}$.). New York, NY: Longman.

Harden, R. M., \& Crosby, J. (2000). The good teacher is more than a lecture - the twelve roles of the teacher. AMEE Medical Education Guide, 22(4), 334-347.

Jagtop, P. (2017). Teacher's role as facilitator in learning. Scholarly Research Journal for Humanity Science \& English Language, 3(17), 3903- 3905.

Khajloo, A. I. (2013). Problems in teaching and learning English for students. International Journal of Engineering Research and Development, 7(3), 56-58. 
Khan, I. A. (2011). Challenges of teaching / learning English and management. Global Journal of Human Social Science, 11(8), 68-80.

Knupfer, N.N. \& McLellan, H. (n.d.). Research methodologies in educational communications and technology. Kansas, KS: McLellanWyat Digital.

Lambert, V.A., \& Lambert, C.E. (2012) Qualitative descriptive research: An acceptable design. Pacific Rim International Journal of Nursing Research, 225. Retrieved from: http://www.tci-thaijo.org.

Marczyk, G., DeMatteo, D., \& Festinger, D. (2005). Essentials of research design and methodology. New York, NY: John Wiley \& Sons, Inc.

Milon, R. K. (2016). Challenges of teaching English at the rural primary schools in Bangladesh: Some recommendations. ELK Asia Pasific Journal of Social Sciences, 2(3). doi: 10.16962/EAPJSS/issn.2394-9392/2014.

Mulyadin, T. (2018). Identity development among muslim Indonesian-American college students: A phenomenological study. Indonesian Research Journal in Education, 2(1), 32-50

Rasheed, S., Zeeshan, M., \& Zaidi, N. A. (2017). Challenges of teaching English language in a multilingual setting: An investigation at government girls' secondary schools of Quetta, Baluchistan, Pakistan. International Journal of English Linguistics, 7(4), 149-157.

Retnawati, H., Djidu, H., Kartianom, Apiano, E., Risqa, \& Anazifa, D. (2018). Teachers' knowledge about higher-order thinking skills and its learning strategy. Problems of Education in the 21th Century, 76(2), 215-230.

Snow, C. E. (2002). Reading for understanding: Toward a research and development program in reading comprehension. Santa Monica, CA: RAN.

Songbatumis, A. M. (2017). Challenges in teaching English at MTsN Taliwang, Indonesia. Journal of Foreign Language Teaching \& Learning, 2(2), 54-67.

Westwood, P. (2008). What teachers need to know about reading and writing difficulties. Victoria, AU: ACER Press. 